\title{
Efektivitas Model Problem Based Learning Ditinjau dari Kemampuan Komunikasi Matematis Siswa
}

\author{
Suci Indah Saputri ${ }^{*}$, Caswita*, Widyastuti \\ Program Studi Pendidikan Matematika Universitas Lampung, Indonesia \\ *Corresponding author: uciindah82@gmail.com
}

\begin{abstract}
The Effectiveness of The Problem Based Learning Model in Terms of Students Mathematical Communication Skills. This research aimed to examine the effectiveness of the problem based learning (PBL) model in terms of students mathematical communication skills. The samples of this research were students of VIII$D$ as many 32 students as experiment class and VIII-D as many 29 students as control class which were chosen by cluster random sampling technique. This research used randomized pretest-posttest control group design. The research data was obtained by test technique through mathematical communication skills tests instrument which form essay question. Reaserch data analized using One Side Proportion Test and Mann Whitney $U$ test. By the rasults of data analysis the students who got score 71 or more of mathematical communication skill in PBL class were not more than $60 \%$ of all students in that class. Gain score mathematical communication skill who treated by PBL more than the students who treated by non PBL. The conclusion of this research is that the PBL model was not effective in term of students mathematical communication skills, but the student's mathematical communication skills who took PBL was higher than students who took non PBL.
\end{abstract}

keywords: problem based learning, mathematical communication, effectivenes

\begin{abstract}
Abstrak: Efektivitas Model Problem Based Learning Ditinjau dari Kemampuan Komunikasi Matematis Siswa. Penelitian ini bertujuan untuk mengetahui efektivitas model problem based learning ditinjau dari kemampuan komunikasi matematis siswa. Sampel penelitian ini adalah siswa kelas VIII D sebanyak 32 siswa sebagai kelas eksperimen dan siswa kelas VIII F sebanyak 29 siswa sebagai kelas kontrol yang dipilih dengan teknik cluster random sampling. Desain yang digunakan adalah randomized pretest-posttest control group design. Data penelitian diperoleh menggunakan teknik tes melalui instrumen tes kemampuan komunikasi matematis yang berbentuk uraian. Analisis data penelitian ini menggunakan uji Proporsi satu pihak dan uji Mann Whitney $U$. Dari hasil analisis data diperoleh bahwa siswa yang memiliki nilai kemampuan komunikasi matematis mencapai 71 setelah mengikuti model PBL tidak lebih dari 60\%. Peningkatan kemampuan komunikasi matematis siswa yang mengikuti model PBL lebih dari peningkatan kemampuan komunikasi matematis siswa yang mengikuti model non PBL. Kesimpulan dari penelitian ini adalah model PBL tidak efektif ditinjau dari kemampuan komunikasi matematis siswa, akan tetapi peningkatan kemampuan komunikasi matematis siswa yang mengikuti PBL lebih dari siswa yang mengikuti non PBL.
\end{abstract}

kata kunci: problem based learning, komunikasi matematis, efektivitas 


\section{PENDAHULUAN}

Pendidikan merupakan salah satu usaha untuk mencerdaskan kehidupan bangsa. Menurut Undang-Undang Nomor 20 Tahun 2003 tentang Sistem Pendidikan Nasional, Pasal 1 ayat 1 menyatakan bahwa pendidikan adalah usaha sadar dan terencana untuk mewujudkan suasana belajar dan proses pembelajaran agar peserta didik secara aktif mengembangkan potensi dirinya untuk memiliki kekuatan spiritual keagamaan, pengendalian diri, kepribadian, kecerdasan, akhlak mulia, serta keterampilan yang diperlukan dirinya, masyarakat, bangsa dan negara.

Dalam pendidikan pasti memuat proses pembelajaran pada tiap jenjang pendidikan. Dalam permendikbud tahun 2016 nomor 22 proses pembelajaran pada satuan pendidikan diselenggarakan secara interaktif, inspiratif, menyenangkan, menantang, memotivasi peserta didik untuk berpartisipasi aktif, serta memberikan ruang yang cukup bagi prakarsa, kreativitas, dan kemandirian sesuai dengan bakat, minat, dan perkembangan fisik serta psikologis peserta didik. Berdasarkan hal tersebut dapat dipastikan bahwa proses pembelajaran terfokus pada peserta didik. Salah satu mata pelajaran di setiap jenjang pendidikan adalah matematika, sebagaimana disebutkan dalam Peraturan Pemerintah Republik Indonesia Nomor 32 Tahun 2013.

Adapun tujuan diberikannya mata pelajaran matematika di sekolah menurut Peraturan Menteri Pendidikan dan Kebudayaan Nomor 58 Tahun 2014 adalah agar peserta didik memiliki kemampuan memahami konsep matematika, menggunakan penalaran, memecahkan masalah, mengomunikasikan gagasan dengan simbol, tabel, diagram, atau media lain untuk memperjelas keadaan atau masalah, dan memiliki sikap menghargai kegunaan matematika dalam kehidupan. Dari uraian tersebut diketahui bahwa kemampuan komunikasi menjadi salah satu kemampuan yang harus dimiliki siswa setelah belajar matematika, sehingga siswa dapat mengemukakan gagasannya kepada orang lain.

Pada pembelajaran matematika komunikasi merupakan hal yang sangat penting, karena komunikasi tidak hanya digunakan dalam sains, tetapi juga digunakan dalam kese-luruhan kegiatan belajar matematika (Fadillah, Armanto, dan Panjaitan, 2012). Komunikasi dalam matema-tika biasa disebut komunikasi matematis merupakan pengungkapan ide-ide atau gagasan menggunakan simbol-simbol sehingga matematika sering juga disebut bahasa simbolik yang dapat membuat penulisan menjadi lebih ringkas. Akan tetapi, kemampuan komunikasi matematis siswa di Indonesia ini masih berada di peringkat yang rendah. Berdasar-kan survei dari Programme Interna-tional for Student Assesment tahun 2015 (OECD, 2018: 7) didapatkan bahwa Indonesia memperoleh skor 386 kurang dari rata-rata skor peserta dari negara-negara anggota Organi-sation for Economic Cooperation and Development (OECD) yaitu 490 dan berada pada peringkat 62 dari 70 negara yang berpartisipasi. Dari hasil survey tersebut diketahui bahwa peringkat Indonesia pada tahun 2015 naik daripada tahun 2012, meskipun masih tergolong dalam peringkat yang rendah. Kemampuan matematika yang menjadi kerangka dalam soal PISA 2015 (OECD, 2013: 13) yaitu komunikasi (communication), literasi matematika (mathematising), representasi (representating), penalaran (reasoning and argument), merancang strategi untuk memecahkan masalah (devising strategies for solving problems), menggunakan simbol (using symbol), menggunakan alat matematika (using mathematical tools). Berdasarkan hal tersebut dapat disimpulkan bahwa kemampuan komunikasi matematis siswa di Indonesia masih tergolong rendah. 
Rendahnya kemampuan komu-nikasi matematis juga terjadi pada siswa kelas VIII SMP Negeri 1 Natar. Berdasarkan penelitian pendahuluan yang telah dilakukan didapatkan hasil yang rendah pada kemampuan komunikasi siswa terutama dalam menggunakan bahasa matematika. Hal ini terlihat dari jawaban yang diberikan siswa dalam menjawab soal tes kemampuan komunikasi matematis terkait materi yang telah dipelajari. Hasil yang diperoleh dari pengujian 31 siswa tidak satupun siswa dapat menjawab soal dengan benar, hal ini dikarenakan siswa-siswa tersebut belum mampu membuat model matematika dari soal yang diberikan sehingga siswa tidak dapat menyelesaikan persoalan dengan benar.

Selain itu, berdasarkan hasil observasi diketahui bahwa sekolah tersebut sudah menggunakan pembelajaran kooperatif atau pembelajaran berkelompok. Meskipun siswa sudah terbiasa dengan pembelajaran berkelompok, tetapi pada pembelajaran tersebut peran guru masih sangat dominan. Siswa lebih banyak menerima materi yang disampaikan oleh guru, dan mengerjakan soal yang diberikan guru. Hal tersebut mempersempit ruang siswa untuk mengembangkan kemampuan komunikasi matematis yang dimilikinya.

Selain karena hal tersebut, pe-nyebab lain yang diduga berpotensi membuat kemampuan komunikasi matematis siswa rendah adalah pem-belajaran yang kurang efektif. Pem-belajaran efektif adalah proses bela-jar yang dapat membuat tujuan pembelajaran dapat tercapai. Untuk itu sangat diperlukan model pembela-jaran yang efektif untuk digunakan dalam proses pembelajaran, agar da-pat meningkatkan kemampuan komunikasi matematis siswa.

Model pembelajaran yang efektif dalam meningkatkan kemampuan komunikasi matematis siswa yaitu model problem based learning. Model Problem based learning (PBL) merupakan model pembelajaran yang dapat mengembangkan kemampuan komunikasi matematis siswa karena proses penyelesaian masalah dapat membuat siswa menjadi terampil dalam menyelesaikan masalah dan diskusi saat proses penyelesaian masalah merupakan forum yang sangat tepat untuk mengembangkan kemampuan komunikasi matematis siswa (Widjajanti, 2011). Dalam PBL siswa dihadapkan pada masalah yang memungkinkan mereka melakukan analisis, menggali informasi, melakukan diskusi, dan mencari solusi dari masalah yang dihadapi. Dengan kegiatan tersebut kemampuan komunikasi matematis siswa akan meningkat dalam menyelesaikan masalah dan menyajikannya dalam simbol-simbol matematika ataupun gambar grafik. Berdasarkan hal tersebut, perlu dilakukan penelitian yang bertujuan untuk mengetahui efektivitas model Problem Based Learning ditinjau dari kemampuan komunikasi matematis siswa kelas VIII SMP Negeri 1 Natar.

\section{METODE}

Penelitian ini dilaksanakan pada semester genap tahun pelajaran 2018/2019 di SMPN 1 Natar. Popu-lasi dalam penelitian ini adalah seluruh siswa kelas VIII SMPN 1 Natar sebanyak 363 siswa yang terdistribusi dalam 11 (sebelas) kelas yaitu kelas VIII A hingga VIII K. Teknik yang digunakan dalam pe-ngambilan sampel adalah teknik cluster random sampling, yaitu me-milih dua kelas sampel secara acak dan terpilihlah dua kelas yaitu kelas VIII D dan kelas VIII F, selanjutnya untuk menentukan kelas eksperimen dan kelas kontrol dilakukan secara random, dan terpilihlah kelas VIII D yang terdiri dari 32 siswa menjadi kelas eksperimen dan kelas VIII F yang terdiri dari 29 siswa menjadi kelas kontrol. 
Penelitian ini terdiri dari satu variabel bebas yaitu model pem-belajaran dan satu variabel terikat yaitu kemampuan komunikasi matematis siswa. Desain penelitian yang digunakan pada penelitian ini adalah randomized pretest-posttest control group design, pemilihan desain tersebut dikarenakan kemampuan komunikasi matematis siswa terkait materi lingkaran belum diketahui sehingga dibutuhkan data siswa sebelum pembelajaran, selain itu untuk memastikan perubahan kemampuan sebelum dan sesudah pembelajaran disebabkan oleh model pembelajaran maka diperlukan kelas kontrol yang menggunakan model non Problem Based Learning.

Prosedur penelitian ini dilaksanakan dalam tiga tahap. yaitu: tahap perencanaan, tahap pelaksanaan, dan tahap pengolahan data. Tahap perencanaan dilakukan untuk melihat karekteristik populasi, menyusun perangkat dan instrumen tes, dan melakukan analisis validitas, reliabilitas, tingkat kesukaran dan daya pembeda instrumen penelitian. Tahap pelaksanaan meliputi pelaksanaan pembelajaran dan melakukan pretest dan postest kemampuan komunikasi matematis. Tahap pengolahan data meliputi pengolahan dan analisis data serta penyusunan laporan hasil penelitian.

Data dalam penelitian ini adalah data kemampuan komunikasi matematis sebelum dan sesudah pembelajaran. Teknik pengumpulan data yang digunakan dalam penelitian ini adalah teknik tes. Tes diberikan sebelum dan setelah dilakukan pembelajaran dikelas eksperimen dan kelas kontrol.

Instrumen yang digunakan da-lam penelitian ini berupa instrumen tes berbentuk uraian materi lingkaran yang disusun berdasarkan indikator pencapaian kompetensi dan indikator kemampuan komunikasi matematis. Idikator kemampuan komunikasi matematis siswa berdasarkan pendapat Cai, Lane dan Jacobsin dalam Fachrurazi yaitu 1) Mengungkapkan kembali suatu uraian matematika dan menjelaskan ide matematika secara tulisan dengan bahasa sendiri, 2) Menggambarkan situasi masalah dalam bentuk gambar, grafik, maupun tabel, 3) Menyelesaikan permasalahan dengan menggunakan rumus, simbol, serta model matematika dengan tepat.

Untuk mendapatkan data yang akurat, instrumen tes yang digunakan dalam penelitian ini harus memenuhi kriteria instrumen tes yang baik. Kriteria instrumen tes yang baik yaitu: valid, reliabel dengan kriteria tinggi atau sangat tinggi, daya pembeda dengan interpretasi cukup, baik atau sangat baik, serta tingkat kesukaran dengan interpretasi mudah, sedang, atau sukar sehingga dapat mengukur kemampuan komunikasi matematis siswa.

Validitas yang digunakan da-lam penelitian ini adalah validitas isi. Validitas isi instrumen tes ini diukur dengan menggunakan daftar cek yang diisi oleh guru mitra dengan cara membandingkan isi yang terkandung dalam instrumen tes kemampuan komunikasi matematis dengan indikator pencapaian kompetensi dan indikator kemampuan komunikasi matematis yang telah ditentukan. Hasil penilaian validitas isi instrumen tes kemampuan komunikasi matematis menunjukan bahwa instrumen tes yang dibuat telah valid. Selanjutnya instrumen tersebut diujicoba kepada siswa yang telah mempunyai kemampuan komunikasi matematis pada materi yang akan di ujikan dan mempunyai kemampuan yang heterogen untuk mengetahui reliabilitas, daya pembeda, dan tingkat kesukaran.

Tabel 1. Rekapitulasi Hasil Uji Coba

\begin{tabular}{lccc}
\hline No & $\begin{array}{c}\text { Reliabilit } \\
\text { as }\end{array}$ & DP & TK \\
\hline
\end{tabular}




\begin{tabular}{|c|c|c|c|}
\hline 1 & \multirow{6}{*}{$\begin{array}{c}0,83 \\
\text { (Tinggi) }\end{array}$} & $\begin{array}{c}\text { Cuku } \\
\mathrm{p} \\
(0,21)\end{array}$ & $\begin{array}{c}\text { Sedan } \\
\mathrm{g} \\
(0,40)\end{array}$ \\
\hline 2 & & $\begin{array}{l}\text { Sanga } \\
\text { t Baik } \\
(0,67)\end{array}$ & $\begin{array}{c}\text { Sedan } \\
\mathrm{g} \\
(0,53)\end{array}$ \\
\hline $3 a$ & & $\begin{array}{l}\text { Sanga } \\
\text { t Baik } \\
(0,54)\end{array}$ & $\begin{array}{c}\text { Sedan } \\
\mathrm{g} \\
(0,51)\end{array}$ \\
\hline $3 b$ & & $\begin{array}{c}\text { Baik } \\
(0,46)\end{array}$ & $\begin{array}{c}\text { Sedan } \\
\mathrm{g} \\
(0,35)\end{array}$ \\
\hline 4 & & $\begin{array}{l}\text { Sanga } \\
\text { t Baik } \\
(0,75)\end{array}$ & $\begin{array}{c}\text { Sedan } \\
\mathrm{g} \\
(0,35)\end{array}$ \\
\hline 5 & & $\begin{array}{c}\text { Baik } \\
(0,38)\end{array}$ & $\begin{array}{c}\text { Sedan } \\
\mathrm{g} \\
(0,51)\end{array}$ \\
\hline
\end{tabular}

Hasil ujicoba instrumen yang didapatkan dianalisis reabilitas, daya pembeda, dan tingkat kesukarannya. Hasil analisis ujicoba instrumen disajikan dalam tabel 1. Berdasarkan Tabel 1, diketahui bahwa instrumen tes kemampuan komunikasi matematis siswa pada penelitian ini telah dinyatakan memenuhi kriteria reliabilitas, tingkat kesukaran dan daya pembeda yang ditentukan, sehingga instrumen tes kemampuan komunikasi matematis telah layak digunakan untuk me-ngumpulkan data.

Data yang terkumpul terdiri dari data pretest dan postest kemam-puan komunikasi matematis kelas eksperimen dan kelas kontrol. Data posttest kemampuan komunikasi matematis kelas eksperimen akan dianalisis untuk mengetahui apakah proporsi siswa dengan nilai minimum 71 setelah mengikuti model PBL lebih dari 60\%. Data pretest dan posttest dari kedua kelas dihitung gain untuk mengetahui apakah peningkatan kemampuan komunikasi matematis siswa yang mengikuti model PBL lebih dari peningkatan kemampuan komunikasi matematis siswa yang mengikuti model non PBL. Analisis dilakukan dengan uji hipotesis. Sebelum melakukan uji hipotesis dilakukan uji prasyarat berupa uji normalitas dan homogenitas.

Hasil uji prasyarat menggunakan uji chi kuadrat yang menunjukkan bahwa data kemampuan komunikasi matematis siswa setelah mengikuti model PBL berasal dari populasi yang berdistribusi normal dan data gain kemampuan komunikasi matematis siswa dari kedua sampel berasal dari populasi yang tidak berdistribusi normal, sehingga uji yang dilakukan adalah Uji proporsi satu pihak dan Uji Mann-Whitney U.

\section{HASIL DAN PEMBAHASAN}

Data kemampuan komunikasi matematis siswa sebelum pembe-lajaran diperoleh dari nilai hasil pretest sedangkan data sesudah pembelajaran diperoleh dari nilai hasil posttest. Data kemampuan komunikasi matematis siswa tersebut disajikan dalam Tabel 2.

Tabel 2. Hasil Analisis Data Nilai Kemampuan Komunikasi Matematis Sebelum dan Sesudah Pembelajaran 
Keterangan

\begin{tabular}{cccccc}
\hline & \multicolumn{2}{c}{$\overline{\boldsymbol{x}}$} & \multicolumn{2}{c}{$\mathbf{s}$} & $\mathbf{P}$ \\
\cline { 2 - 6 } & $\mathrm{A}$ & $\mathrm{B}$ & $\mathrm{A}$ & $\mathrm{B}$ & $\mathrm{B}$ \\
\hline \multirow{2}{*}{$\mathrm{E}$} & 12,0 & 40,6 & 6,8 & 15,9 & 0,1 \\
& 7 & 1 & 2 & 2 & 0 \\
\hline \multirow{2}{*}{$\mathrm{K}$} & 9,20 & $\begin{array}{c}27,7 \\
8\end{array}$ & $\begin{array}{c}6,4 \\
1\end{array}$ & $\begin{array}{c}17,5 \\
1\end{array}$ & $\begin{array}{c}0,0 \\
3\end{array}$ \\
\hline
\end{tabular}

$\begin{array}{ll}\text { A } & \begin{array}{l}: \text { Kemampuan Sebelum } \\ \text { Pembelajaran }\end{array} \\ \text { B } & : \text { Kemampuan Sesudah } \\ & \text { Pembelajaran } \\ \text { E } & : \text { Kelas Eksperimen } \\ \text { K } & : \text { Kelas Kontrol } \\ \bar{x} & : \text { Rata-rata nilai }\end{array}$

Berdasarkan Tabel 2 diketahui bahwa rata-rata kemampuan komunikasi matematis sebelum maupun sesudah mengikuti pembelajaran model PBL lebih dari rata-rata kemampuan komunikasi matematis siswa sebelum maupun sesudah pembelajaran non PBL. Artinya kemampuan komunikasi matematis siswa yang mengikuti model PBL lebih dari kemampuan komunikasi matematis siswa yang mengikuti non PBL.

Dari Tabel 2 juga dapat dike-tahui bahwa simpangan baku ke-mampuan komunikasi matematis sis-wa sebelum mengikuti pembelajaran menggunakan model PBL lebih dari siswa sebelum mengikuti pembelajaran non PBL. Sedangkan simpangan baku dari kemampuan komunikasi matematis siswa sesudah mengikuti pembelajaran menggunakan model PBL kurang dari simpangan baku kemampuan komunikasi matematis siswa sesudah mengikuti pembelajaran non PBL. Artinya, komunikasi matematis siswa sebelum mengikuti pembelajaran dengan model PBL lebih heterogen daripada kemampuan komunikasi matematis siswa sebelum mengikuti pembelajaran dengan model non PBL dan komunikasi matematis siswa sesudah mengikuti pembelajaran dengan model PBL lebih homogen daripada siswa dengan model non PBL.

Dilihat dari proporsi siswa yang mempunyai nilai kemampuan komunikasi matematis mencapai 71 pada kelas sesudah mengikuti model PBL lebih dari proporsi siswa yang mempunyai nilai kemampuan komu-nikasi matematis mencapai 71 pada kelas sesudah mengikuti model non PBL. Artinya, proporsi siswa yang mampu mencapai ketuntasan belajar sesudah mengikuti model PBL lebih dari proporsi siswa yang mampu mencapai ketuntasan belajar sesudah mengikuti model non PBL.

Tabel 3. Hasil Analisis Data Gain Kemampuan Komunikasi Matematis

\begin{tabular}{ccc}
\hline & $\overline{\boldsymbol{x}}$ & $\mathbf{s}$ \\
\hline $\mathrm{E}$ & 0,33 & 0,171 \\
\hline $\mathrm{K}$ & 0,21 & 0,173 \\
\hline
\end{tabular}

Data gain kemampuan komu-nikasi matematis siswa diperoleh dari perhitungan dengan rumus gain ternormalisasi yaitu selisih antara nilai kemampuan sesudah pembelaja-ran dan nilai kemampuan sebelum pembelajaran dibagi selisih antara nilai 
maksimal dan nilai kemampuan sebelum pembelajaran. Rekapitulasi data gain kemampuan komunikasi matematis siswa pada kelas ekspe-rimen dan data gain kemampuan komunikasi matematis siswa pada

kelas kontrol disajikan pada Tabel 3.

Berdasarkan Tabel 3 dapat dilihat bahwa rata-rata gain kemampuan komunikasi matematis siswa yang mengikuti pembelajaran mengguna-kan model PBL lebih dari siswa yang mengikuti pembelajaran non PBL. Sedangkan simpangan baku gain siswa yang mengikuti pembelajaran non PBL lebih dari simpangan baku gain siswa yang mengikuti pembelajaran dengan model PBL. Artinya, peningkatan kemampuan komunikasi matematis yang mengikuti pembelajaran dengan menggunakan model PBL lebih heterogen dari peningkatan kemampuan komunikasi matematis siswa yang mengikuti pembelajaran non PBL.

Tabel 4. Hasil Analisis Pencapaian Indikator Kemampuan Komunikasi Matematis Sebelum Pembelajaran

\begin{tabular}{|c|c|c|}
\hline Indikator & $\mathbf{E}$ & $\mathbf{K}$ \\
\hline $\begin{array}{l}\text { Mengungkapkan } \\
\text { kembali suatu uraian } \\
\text { matematika dan } \\
\text { menjelaskan ide ma- } \\
\text { tematika secara } \\
\text { tulisan dengan } \\
\text { bahasa sendiri. }\end{array}$ & $20 \%$ & $\begin{array}{l}21 \\
\%\end{array}$ \\
\hline $\begin{array}{l}\text { Menggambarkan } \\
\text { situasi masalah } \\
\text { dalam } \quad \text { bentuk } \\
\text { gambar, grafik, } \\
\text { maupun tabel. }\end{array}$ & $0 \%$ & $2 \%$ \\
\hline $\begin{array}{l}\text { Menyelesaikan } \\
\text { perma-salahan } \\
\text { dengan meng- } \\
\text { gunakan rumus, } \\
\text { simbol, serta model } \\
\text { matematika dengan } \\
\text { tepat. }\end{array}$ & $17 \%$ & $5 \%$ \\
\hline Rata-rata & $12 \%$ & $9 \%$ \\
\hline
\end{tabular}

Berdasarkan Tabel 4 terlihat bahwa rata-rata pencapaian indikator kemampuan komunikasi matematis siswa sebelum pembelajaran pada kelas eksperimen lebih dari rata-rata pencapaian indikator kemampuan komunikasi matematis siswa sebelum pembelajaran pada kelas kontrol. Analisis pencapaian indikator ke-mampuan komunikasi matematis siswa sesudah pembelajaran pada kelas eksperimen dan pencapaian indikator kemampuan komunikasi matematis sesudah pembelajaran pada kelas kontrol disajikan dalam Tabel 5. 
Tabel 5. Hasil Analisis Pencapaian Indikator Kemampuan Komunikasi Matematis Sesudah Pembelajaran

\begin{tabular}{|c|c|c|}
\hline Indikator & $\mathbf{E}$ & $\mathbf{K}$ \\
\hline $\begin{array}{l}\text { Mengungkapkan } \\
\text { kembali suatu uraian } \\
\text { matematika dan } \\
\text { menjelaskan ide ma- } \\
\text { tematika secara } \\
\text { tulisan dengan } \\
\text { bahasa sendiri. }\end{array}$ & $40 \%$ & $\begin{array}{l}38 \\
\%\end{array}$ \\
\hline $\begin{array}{l}\text { Menggambarkan } \\
\text { situasi masalah } \\
\text { dalam } \quad \text { bentuk } \\
\text { gambar, grafik, } \\
\text { maupun tabel. }\end{array}$ & $46 \%$ & $\begin{array}{l}18 \\
\%\end{array}$ \\
\hline $\begin{array}{l}\text { Menyelesaikan } \\
\text { perma-salahan } \\
\text { dengan meng- } \\
\text { gunakan rumus, } \\
\text { simbol, serta model } \\
\text { matematika dengan } \\
\text { tepat. }\end{array}$ & $36 \%$ & $\begin{array}{l}27 \\
\%\end{array}$ \\
\hline Rata-rata & $41 \%$ & $\begin{array}{l}28 \\
\% \\
\end{array}$ \\
\hline
\end{tabular}

Berdasarkan Tabel 5 terlihat bahwa rata-rata pencapaian indikator ke-mampuan komunikasi matematis sis-wa sesudah pembelajaran kelas eks-perimen lebih dari kelas kontrol. Dari Tabel 4 dan Tabel 5 dapat diketahui bahwa kenaikan rata-rata pencapaian indikator dari kemam-puan komunikasi matematis siswa sebelum ke sesudah pembelajaran pada kelas eksperimen lebih dari kelas kontrol. Artinya, pencapaian indikator kemampuan komunikasi matematis pada kelas eksperimen mengalami peningkatan yang lebih dari kelas kontrol.

Setelah data dianalisis dilaku-kan uji hipotesis untuk mengetahui apakah model PBL efektif. Berdasar-kan uji prasyarat, diketahui bahwa data kemampuan komunikasi mate-matis siswa setelah mengikuti model PBL berasal dari populasi yang berdistribusi normal. Oleh karena itu, pengujian hipotesis statistik dilaku-kan dengan menggunakan uji pro-porsi satu pihak.

Proporsi siswa yang mempuyai nilai minimum 71 adalah 3 dari 29 siswa, sehingga diperoleh hasil $z_{\text {hitung }}=-5,45831$, sedangkan pada taraf nyata 0,05 diperoleh hasil $z_{\text {tabel }}=1,64$. Karena $z_{\text {hitung }}=-5,45831<1,64=z_{\text {tabel }}$ maka $H 0$ diterima. Artinya, proporsi siswa yang memiliki kemampuan komunikasi matematis dengan nilai minimum 71 pada kelas dengan model PBL tidak lebih dari 60\%. Hal tersebut menunjukkan bahwa model PBL tidak efektif ditinjau dari kemam-puan komunikasi matematis siswa, akan tetapi kemampuan komunikasi matematis siswa yang mengikuti problem based learning lebih dari siswa yang mengikuti non problem based learning, untuk membuktikan hal tersebut maka dilakukan uji kesamaan data gain kemampuan komunikasi matematis siswa. 
Berdasarkan uji prasyarat, di-ketahui bahwa kedua sampel data gain komunikasi matematika berasal dari populasi yang tidak berdistribusi normal. Oleh karena itu, pengujian hipotesis statistik dilakukan dengan menggunakan uji non parametrik yaitu uji Mann Whitney $U$. Rekap-itulasi data hasil uji ini dapat dilihat pada Tabel 6 .

Berdasarkan Tabel 6 dapat dilihat bahwa pada taraf nyata 0,05 diperoleh $\left|z_{\text {hitung }}\right|=|-2,8093|=2,8093>z_{\text {tabel }}=-1,64$ sehingga $\mathrm{H}_{0}$ ditolak. Artinya, peningkatan ke-mampuan komunikasi matematis siswa yang mengikuti model PBL lebih dari peningkatan kemampuan komunikasi matematis siswa yang mengikuti non PBL.

Tabel 6. Hasil Uji Mann Whitney $U$

\begin{tabular}{cccc}
\hline $\begin{array}{c}\text { Kela } \\
\mathbf{S}\end{array}$ & $\begin{array}{c}\text { Statistik } \\
\boldsymbol{U}\end{array}$ & $\boldsymbol{z}_{\text {hitung }}$ & $\boldsymbol{z}_{\text {tabel }}$ \\
\cline { 1 - 2 } $\mathrm{E}$ & 269,5 & $-2,8093$ & $-1,64$ \\
\cline { 1 - 2 } $\mathrm{K}$ & 656 & & \\
\hline
\end{tabular}

Berdasarkan hasil uji proporsi yang telah dilakukan menunjukkan bahwa proporsi siswa yang memiliki kemampuan komunikasi matematis dengan nilai minimum 71 setelah mengikuti model PBL tidak lebih dari 60\%. Sedangkan pada hasil uji kesamaan yang telah dilakukan me-nunjukkan bahwa peningkatan ke-mampuan komunikasi matematis sis-wa yang mengikuti model PBL lebih dari peningkatan kemampuan komunikasi matematis siswa yang meng-ikuti model non PBL. Hal ini sejalan dengan hasil penelitian yang dila-kukan oleh Dianna (2018) dan Chatarina (2015) bahwa model PBL tidak efektif ditinjau dari kemampuan komunikasi matematis siswa.

Hal-hal yang menyebabkan banyaknya siswa yang memiliki kemampuan komunikasi matematis dengan nilai minimum 71 setelah mengikuti model PBL tidak lebih dari $60 \%$ dikarenakan siswa belum terbiasa dalam menyelesaikan per-masalahanpermasalahan yang tidak terstruktur dan hanya sebagian siswa yang terlibat aktif dalam proses diskusi sedangkan sebagian yang lain cenderung pasif serta beberapa siswa kurang antusias dan tidak memiliki semangat belajar membuat penye-lesaian permasalahan tidak tercapai dengan baik, sesuai dengan pendapat Hamalik dalam Permatasari (2019) yang mengatakan bahwa belajar tanpa adanya semangat sulit untuk mencapai keberhasilan secara opti-mal. Selain itu terbatasnya sumber belajar siswa membuat pengetahuan siswa menjadi terbatas sehingga mempengaruhi hasil belajar. Hal ini sejalan dengan hasil penelitian yang dilakukan oleh Lestari (2016) dan Amris (2015) bahwa sumber belajar mempengaruhi hasil belajar siswa.

Waktu pembelajaran yang singkat juga menjadi salah satu fak-tor kendala dalam pelaksanaan pene-litian ini. Siswa yang belum terbiasa menyelesaikan permasalahan kon-tekstual terkait materi lingkaran merasakan kesulitan dalam menye-lesaikan masalah, dan hal tersebut membuat waktu yang telah diberikan tidak cukup untuk menyelesaikan permasalahan yang diberikan.

Pada pertemuan pertama dan kedua siswa masih bingung dengan apa yang harus dikerjakan dan bagaimana menyelesaikan permasa-lahan yang diberikan, hal ini terlihat dari hasil diskusi dimana tidak ada kelompok yang mampu menye-lesaikan permasalahan yang dibe-rikan meskipun guru telah menuntun siswa dan memberikan 
umpan agar siswa dapat menyelesaikan perma-salahan. Pada pertemuan-pertemuan selanjutnya siswa mulai terbiasa di-berikan permasalahan sehingga permasalahan dapat diselesaikan oleh beberapa kelompok meskipun masih ada kelompok yang belum dapat menyelesaikan permasalahan karena waktu pembelajaran telah usai. Pada pertemuan kelima dan keenam baru-lah siswa terbiasa dengan perma-salahan-permasalahan yang diberi-kan sehingga semua kelompok dapat menyelesaikan permasalahan sesuai dengan waktu yang diberikan meski-pun tidak semua kelompok menye-lesaikan dengan benar.

Selain itu, dalam pelaksanaan pembelajaran terdapat salah satu fase yang tidak dilaksanakan secara maksimal yaitu pada fase menya-jikan hasil karya. Pada fase tersebut banyak siswa yang tidak percaya diri untuk menyajikan hasil pekerjaan kelompoknya sehingga penyajian hasil pekerjaan siswa dilakukan seadanya. Padahal percaya diri merupakan hal yang penting bagi siswa agar berhasil dalam belajar matematika (Yates, 2002).

Kendala yang terjadi pada fase menyajikan hasil karya tersebut berdampak pada fase selanjutnya yaitu fase menganalisa dan meng-evaluasi proses penyelesaian masalah. Karena penyajian hasil karya yang kurang maksimal menyebabkan kelompok lain kurang memperhatikan penyampaian hasil karya sehingga proses analisa dan evaluasi penyelesaian masalah tidak mampu dilakukan sendiri oleh siswa dan akhirnya fase tersebut dilakukan oleh guru yang mengajar.

Walaupun model PBL tidak efektif ditinjau dari kemampuan komunikasi matematis siswa, tetapi peningkatan kemampuan komunikasi matematis siswa yang mengikuti model PBL lebih dari peningkatan kemampuan komunikasi matematis siswa yang mengikuti model non PBL. Hal ini dikarenakan pada kelas yang mengikuti model PBL siswa dihadapkan pada suatu permasalahan kontekstual sehingga proses diskusi menjadi lebih hidup dikarenakan se-tiap siswa mempunyai pemikiran yang berbeda, dan dengan adanya bermacam-macam ide yang dimiliki siswa, membuat siswa harus bijak memilih ide-ide yang tepat untuk menyelesaikan permasalahannya.

Dalam menyelesaikan permasalahan-permasalahan yang diberikan, siswa dibantu dengan adanya aktivitas yang terdapat pada LKPD sehingga ide-ide siswa menjadi lebih terbangun dan terarah untuk menyelesaikan masalah, sedangkan pada kelas kontrol siswa hanya diberikan aktivitas-aktivitas yang dapat menjadi pendukung materi, sehingga diskusi tergolong pasif karena siswa terfokus untuk menyelesaikan aktivitas dan meskipun aktivitas tersebut merupakan aktivitas kelompok tetapi banyak siswa yang menyelesaikan aktivitas secara individu dengan saling berbagi tugas.

Siswa pada kelas PBL juga diajak membangun pemahamannya secara mandiri melalui fase-fase pada model PBL seperti fase pertama (orientasi peserta didik pada masalah), fase kedua (mengorganisasi peserta didik untuk belajar), dan fase ketiga (membimbing penyelidikan individual maupun kelompok). Pada tiga fase awal ini siswa akan membangun sendiri pemahamannya dan mengembangkan pemahaman tersebut untuk menyelesaikan permasalahan yang telah diberikan. Selain membangun pemahamannya secara mandiri siswa juga lebih terlatih untuk bertukar ide dan berdiskusi degan teman kelompoknya. Sedangkan pada fase keempat (mengembangkan dan menyajikan hasil karya) dan fase kelima (menganalisis dan mengevaluasi proses pemecahan masalah) siswa akan melatih kemampuan komunikasinya saat presentasi dan memperkokoh pemahaman yang sudah dibangun dengan adanya proses analisis dan evaluasi. Hal ini sangat berbeda dengan siswa pada kelas non-PBL karena siswa tidak membangun sendiri pemahamannya tetapi mereka memperoleh pemahaman dari materi 
yang diberikan oleh guru sehingga pemahamannya menjadi terbatas dan dapat dengan mudah terlupakan.

Selain itu dilihat dari rata-rata pencapaian indikator kemampuan komunikasi matematis siswa yang mengikuti model PBL pada indikator mengungkapkan kembali suatu urai-an matematika dan menjelaskan ide matematika secara tulisan dengan bahasa sendiri (written text) ke-mampuan siswa yang semula $20 \%$ setelah pembelajaran mencapai $40 \%$, artinya kemampuan siswa setelah pembelajaran mengalami peningkatan dua kali lebih baik dari kemampuan awalnya.

Pada indikator menyelesaikan permasalahan dengan menggunakan rumus, simbol, serta model matematika dengan tepat (mathematical expression) kemampuan siswa yang mengikuti model PBL yang semula 17\% setelah pembelajaran kemampuannya menjadi $36 \%$, artinya kemampuan siswa setelah pembelajaran meningkat sekitar dua kali lebih baik dari kemampuan awalnya.

Pada indikator menggambarkan situasi masalah dalam bentuk gambar, grafik, maupun tabel (drawing) kemampuan siswa yang semula 0\% setelah pembelajaran mencapai $46 \%$, artinya siswa yang sebelumnya tidak memiliki kemampuan pada indikator tersebut setelah pembelajaran kemampuannya menjadi cukup baik. Hal ini menunjukkan bahwa siswa yang mengikuti model PBL mengalami peningkatan kemampuan komunikasi matematis minimal dua kali lebih baik dari kemampuannya sebelum mengikuti model PBL.

\section{KESIMPULAN}

Berdasarkan hasil analisis data diperoleh bahwa peningkatan ke-mampuan komunikasi matematis siswa yang mengikuti model PBL lebih dari peningkatan kemampuan komunikasi matematis siswa yang mengikuti model non PBL, tetapi kemampuan komunikasi matematis siswa dengan nilai minimum 71 setelah mengikuti model PBL tidak lebih dari 60\%, sehingga dapat disimpulkan bahwa model PBL tidak efektif ditinjau dari kemampuan komunikasi matematis siswa kelas VIII SMP Negeri 1 Natar Tahun Pelajaran 2018/2019.

\section{REFERENSI}

Amris, Wayas Shirly. 2015. Pengaruh Penggunaan Sumber Belajar Terhadap Prestasi Belajar IPS. Jurnal Pedagogi. (Online), Vol. 3, No. 5, (http://jurnal.fkip. unila.ac.id/index.php/pgsd/article/view/9330/5963), diakses 6 Mei 2019.

Chatarina, Enggar Fathia. 2015. Efektivitas Penerapan Model Problem Based Learning Ditinjau Dari Kemampuan Komunikasi Matematis Siswa. Jurnal Pendidikan Matematika Unila. (Online), Vol. 3, No. 1, (http://jurnal.fkip.unila.ac.id/ index.php/MTK/article/view/7968/4798), diakses 30 April 2019.

Dianna, Septi Bunga Mulia. 2018. Efektivitas Problem Based Learning Terhadap Kemampuan Komunikasi Matematis Siswa. Jurnal Pendidikan Matematika Unila. (Online), Vol. 6, No. 6, (http://jurnal.fkip.unila.ac.id/index.php/MTK/ article/view/7968/4798), diakses 30 April 2019.

Fadilah, Armanto, D., \& Panjaitan. 2012. Kemampuan Komunikasi Matematis Siswa Sekolah Menengah Pertama Dan Madrasah Tsanawiyah Pada Materi Fungsi Di P. Brandan Kabupaten Langkat. Jurnal Pendidikan Matematika PARADIGMA. (Online), Vol. $\quad 5, \quad$ No. $\quad 2, \quad$ (http://digilib. unimed.ac.id/752/1/kemampuan/\%20komunikasi\%20matematis\%20siswa\%20sek olah\%20menengah\%20pertama\%20dan\%20madrasah\%20tsanawiyah\%20pada $\% 2$ 
0materi\%20fungsi\%20di\%20P.Brandan\%20Kabupaten\%20Langkat), diakses pada 9 Oktober 2018.

Fachrurazi. 2011. Penerapan Pembelajaran Berbasis Masalah untuk Meningkatkan Kemampuan Berpikir Kritis dan Komunikasi Matematis Siswa Sekolah Dasar. Jurnal UPI Edisi Khusus. (Online), Edisi Khusus, No. 1, (http://jurnal.upi.edu/file/8-Fachrurazi.pdf.), diakses pada 31 Oktober 2017.

Permendikbud. 2013. Permendikbud 32 tahun 2013 tentang standar nasional pendidikan. Jakarta: Kementrian pendidikan dan kebudayaan.

Permendikbud. 2016. Lampiran Permendikbud 21 tahun 2016 tentang Standar Isi Pendidikan. Jakarta: Kementrian pendidikan dan kebudayaan.

Lestari, Bunga Indah. 2016. Pengaruh Penggunaan Sumber Belajar Terhadap Hasil Belajar Mata Pelajaran Ekonomi. Jurnal Pendidikan dan Pembelajaran. (Online), Vol. 5, No. 7, (http://jurnal.untan.ac.id/index.php/jpdpb/article/view/16108/14046 diakses 6 mei 2019.

Organisation for Economic Cooperation and Development (OECD). 2013. Draft Mathematics Framework. (Online), (http://oecd.org/pisa/ pisaproducts/Draft\%20Mathematics\%20Framework\%20.pdf), diakses 6 Desember 2018.

Organisation for Economic Cooperation and Development (OECD). 2016. Program for International Student Asssessment (PISA) Result from PISA 2015. (Online), (http://oecd.org/pisa/Pisa-2015-Indonesia.pdf), diakses 7 Mei 2018.

Permatasari, Dwi. 2019. Efektivitas Model Problem Based Learning Ditinjau dari Kemampuan Komunikasi Matematis Siswa. Jurnal Pendidikan Matematika. (Online), Vol. 7, No. (http://jurnal.fkip.unila.ac.id/index.php/MTK/article/view/17603/pdf), diakses 6 mei 2019.

Widjayanti, Djamilah Bondan. 2011. Mengembangkan kecakapan matematis mahasiswa calon guru matematika melalui strategi perkuliahan kolaboratif berbasis masalah. Prosiding seminar nasional penelitian. (Online), (https://scholar.goo gle.co.id/citations?user=F1i-yTQAAAAJ\&hl=id\#d=gs_md_cita$\mathrm{d} \& \mathrm{u}=\% 2 \mathrm{Fcitations} \% 3 \mathrm{~F}$ view_op\%3Dview_citation\%26hl\%3Did\%26user\%3DF1iyTQAAAAJ\%26citation_for_view\%3DF1i-yTQAAAAJ\%3 AZph67rFs4hoC\%26tzom\%3d-420), diakses 7 mei 2018.

Yates. 2002. The Influence Of Optimism And Pesimism On Student Achievment In Mathematics. Mathematics Education Reaserch Journal, (Online), Vol. 14, No. 1, (http://www.merga.net.au/documents/MERJ_14_1_Yates.pdf), diakses pada 6 mei 2018. 